\title{
MICROAMBLYSTEGIUM - A NEW GENUS OF AMBLYSTEGIACEAE FROM SHIKOTAN ISLAND (SOUTH KURILS, RUSSIAN FAR EAST)
}

\section{MICROAMBLYSTEGIUM - НОВЫЙ РОД МХОВ ИЗ СЕМЕЙСТВА AMВLYSTEGIACEAE С ОСТРОВА ШИКОТАН (ЮЖНЫЕ КУРИЛЫ, РОССИЙСКИЙ ДАЛЬНИЙ ВОСТОК)}

\author{
Vladimir E. Fedosov ${ }^{1,2}$, Elena A. IGNATOVA ${ }^{1}$, Alina V. Fedorova ${ }^{3} \&$ JAN KUČERA $^{4}$ \\ ВЛАДИМИР Э. ФЕДОСОВ ${ }^{1,2}$, ЕЛЕНА А. ИГНАТОВА ${ }^{1}$, АЛИНА В. ФЕДОРОВА ${ }^{3}$, ЯН КУЧЕРА $^{4}$
}

Abstract

\begin{abstract}
A molecular phylogenetic study based on the plastid $\operatorname{trn} \mathrm{L}-\operatorname{trn} \mathrm{F}$, atp B-rbcL and nuclear ITS sequences resolved an unnamed tiny saxicolous moss recently collected in Shikotan Island in a clade with Kandaea, Palustriella and Cratoneuron. At the same time, it markedly differs from them morphologically in having homogeneous stem cross section, weak single costa reaching only 0.3 to 0.7 of leaf length, and very weakly differentiated alar cells. The moss is therefore described here as Microamblystegium saxicola gen. and sp. nov. We speculate that it represents another specialized evolutionary lineage with miniaturized and simplified morphology likely associated with adaptation to growth in shaded cliff niches, matching a similar pattern observed in the recently described amblystegiaceous genus Arvernella. Such specialized lineages of minute saxicolous mosses remain poorly known due to their outstanding rarity.
\end{abstract}

Резюме

Молекулярно-филогенетическое исследование, основанное на последовательностях пластидных маркеров $t r n \mathrm{~L}-t r n \mathrm{~F}, a t p \mathrm{~B}-r b c \mathrm{~L}$ и ядерного ITS доказало принадлежность миниатюрного эпилитного мха, собранного на острове Шикотан к кладе, также включающей роды Kandaea, Palustriella и Cratoneuron. В то же время он сильно отличается от них по морфологии, поскольку имеет стебель, гомогенный на поперечном срезе и сравнительно слабую простую жилку от 0.3 до 0.7 длины листа, а также слабо дифференцированные клетку в углях основания листа. Этот мох описан как Microamblystegium saxicola gen. and sp. nov. На основании молекулярно-филогенетических данных мы предполагаем, что он представляет еще одну специализированную филогенетическую линию, эволюция которой пошла по пути миниатюризации и упрощения морфологии, вероятно в связи с адаптацией к произрастанию в нишах скал, подобно недавно описанному в этом же семействе роду Arvernella. Такие специализированные группы мелких эпилитных мхов остаются слабо изученными ввиду их исключительной редкости.

KEYWORDS: Hypnales, molecular phylogeny, cryptic diversity, parallel evolution

\section{INTRODUCTION}

Among the collections from a recent expedition to Shikotan Island (South Kurils), we were puzzled by a specimen of a small saxicolous amblystegiaceous moss, which resembled species of the tiny amblystegiaceous genera Serpoleskea (Hampe ex Limpr.) Loeske, Pseudoamblystegium Vanderp. \& Hedenäs or the recently described Arvernella pisarenkoi Ignatov \& Ignatova (Ignatov et al., 2021). With respect to the little informative morphology of these mosses and having in mind the proved morphological parallelism among phylogenetically unrelated genera Platydictya Berk., Heterocladium Schimp., Arvernella Hugonnot \& Hedenäs, Serpoleskea or Pseudoamblystegium, confident identifica- tion based solely on morphological ground is problematic. Therefore, we decided to explore the affinities of the newly found moss using molecular data. As we expected the unknown moss to be most likely member of Amblystegiaceae, our initial barcoding attempt included nrITS and chloroplast $a t p \mathrm{~B}-r b c \mathrm{~L}$, two regions for which Amblystegiaceae have been rather well sampled in the course of earlier molecular phylogenetic studies (e.g., Vanderpoorten et al., 2001, 2002; Kučera \& Hedenäs, 2020; Ignatov et al., 2021). These first obtained sequences, evaluated within an unpublished dataset by JK, showed an unexpected affinity with species from the clade containing members of Cratoneuron (Sull.) Spruce, Palustriella Ochyra, and the recently described Kandaea Jan

\footnotetext{
1 - Lomonosov Moscow State University, Biological Faculty, Geobotany Dept., Leninskie Gory Str. 1-12, Moscow 119991 Russia; email: fedosovvv@mail.ru

2 - Botanical Garden-Institute, FEB RAS, Makovskogo Street, 142, Vladivostok, 690024, Russia

3 - Tsitsin Main Botanical Garden, Russian Academy of Sciences, Botanicheskaya Str., 4, Moscow 127276 Russia; e-mail: misha_ignatov@list.ru

${ }^{4}$ - Faculty of Science, Department of Botany, University of South Bohemia, České Budějovice, Czech Republic
} 
Kučera \& Hedenäs, rather than to Arvernella, Amblystegium Schimp., Serpoleskea or Pseudoamblystegium in which similar tiny morphotypes occur.

Therefore, we decided to compile a comprehensive dataset, aiming to obtain more solid evidence of molecular affinities of this unknown moss, which could either support the inclusion in one of existing genera in the Amblystegiaceae or prove the need for establishing a new genus for this moss.

\section{MATERIALS AND METHODS}

\section{Dataset}

Since search for related taxa via blast and quick phylogenetic reconstructions based on ITS and the atp $\mathrm{B}-$ $r b c \mathrm{~L}$ spacer revealed its affinity with morphologically rather dissimilar mosses, we performed a phylogenetic reconstruction of the Amblystegiaceae based on a dataset combining $a t p \mathrm{~B}-r b c \mathrm{~L}$ spacer and $t r n \mathrm{~L}-t r n \mathrm{~F}$ region with nuclear ITS1-5.8S rRNA-ITS2. Sequences were obtained according to the protocols described by Gardiner et al. (2005), and Kučera et al. (2019). The core of the dataset originated from the recent study by Kučera \& Hedenäs (2020). Our molecular dataset included 68 accessions including 57 representatives of the Amblystegiaceae. For GenBank accession numbers and voucher information of newly studied specimens see Fig. 1 and Appendix 1.

Three datasets used for phylogenetic inferences included 68 terminals and corresponded to the combined $\operatorname{trn} \mathrm{L}-t r n \mathrm{~F} \& a t p \mathrm{~B}-r b c \mathrm{~L}$ sequences (1228 aligned positions), nr ITS (924 positions) and their concatenation (2152 positions plus indels). Sequences were aligned using the E-INS-i strategy in MAFFT v. 7.487 (Katoh \& Standley, 2013) and then edited manually in BioEdit (Hall, 1999). Indel data were scored using simple indel coding approach (Simmons and Ochoterena 2000) using SeqState 1.4.1. (Müller 2005). One of two alternative states of highly homoplasic inversion in the trnL-trnF spacer was coded as indel that allowed its inclusion in the analysis as a single mutation, not three substitutions. The combined dataset was divided into partitions using the algorithm described by Kučera \& Hedenäs (2020) except for indels, which were divided into two partitions, corresponding to nuclear (151 indels) and plastid (66 indels) data.

Molecular phylogenetic analyses

Phylogenetic analysis was performed using Bayesian Inference by running two parallel analyses in MrBayes 3.2.7a (Ronquist et al., 2012) with each run consisting of six Markov chains and 5,000,000 generations. The sampling frequency was one tree each 1000 generations, and the chain temperature was set at 0.03 in all analyses and sampling across the GTR model space. Consensus trees were calculated after omitting the first $25 \%$ trees as burn-in. Convergence of analyses was assessed based on average PSRF values (1.000 in both analyses) and ESS values, checked using Tracer v.1.7.2. (Rambaut et al., 2018 ) to be higher than 200. Analyses were performed on the Cipres Science Gateway (http://www.phylo.org/ portal2) on XSEDE (Miller et al., 2010). Maximum Likelihood (ML) trees were estimated using RaxML 8.2.12 (Stamatakis, 2014). ML analyses were run at the cluster computer facilities of MetaCentrum VO (see acknowledgement) on identical matrices, the bootstrap analysis was stopped automatically using the autoMRE command. For ML analysis, the GTR model was used. Trees were rooted with the Scorpidiaceae clade in all analyses according to the topology of hypnalean mosses presented by Kučera et al. (2019).

\section{RESULTS}

The topologies of the ITS based trees are congruent with those based on the plastid dataset. Since the topology of the obtained single gene trees repeats already published ones with minor differences caused by different compositions of datasets, they are not considered here in details.

In the tree inferred from the combined dataset (Fig. 1) accessions of the Amblystegiaceae form a moderately supported clade sister to the Leskeaceae + Rhytidiaceae + Pseudoleskeellaceae clade. Within the Amblystegiaceae clade, a clade consisting of two accessions of Myrinia pulvinata (Wahlenb.) Schimp. split first, followed by the weakly supported Drepanium (Schimp.) Lange \& C.E.O. Jensen, Platyhypnum Loeske, Campylophyllum (Schimp.) M. Fleisch. and Arvernella clade and the single accession of Tomentypnum nitens (Hedw.) Loeske, which forms a moderately supported sister group to the core Amblystegiaceae clade. The maximally supported core Amblystegiaceae clade includes four maximally supported major clades in a grade. These major clades include accessions of (1) Leptodictyum (Schimp.) Warnst. within which two remarkably distinct lineages appear; (2) Kandaea, Cratoneuron, Palustriella and the recently collected plant from Shikotan; (3) Amblystegium, Hygroamblystegium Loeske, Drepanocladus (Müll. Hal.) G. Roth, Cratoneuropsis (Broth.) M. Fleisch., Hypnobartlettia Ochyra, and Vittia Ochyra; (4) Anacamptodon Brid., Campylium (Sull.) Mitt., Campylophyllopsis W.R. Buck, Hygrohypnum Lindb., Microhypnum Jan Kučera \& Ignatov, Pseudoamblystegium, Pseudocampylium Vanderp. \& Hedenäs, and Serpoleskea.

The specimen from Shikotan was found in a wellsupported C2 clade of core Amblystegiaceae as delimited by Kučera \& Hedenäs (2020), where it forms a marginally supported clade with accessions of Palustriella.

\section{DISCUSSION}

The topologies of the obtained trees are congruent with those obtained in earlier studies focused on the Amblystegiaceae (Vanderpoorten et al. 2001, 2002; Kučera \& Hedenäs, 2020; Ignatov et al., 2021). The Arvernella clade was found deeply nested in the maximally supported $\mathrm{C} 1$ clade of the Amblystegiaceae, which also includes Drepanium, Platyhypnum and Campylophyllum (cf. Kučera \& Hedenäs, 2020), and similar affinity was suggested by Hugonnot \& Hedenäs (2015) and Ignatov 


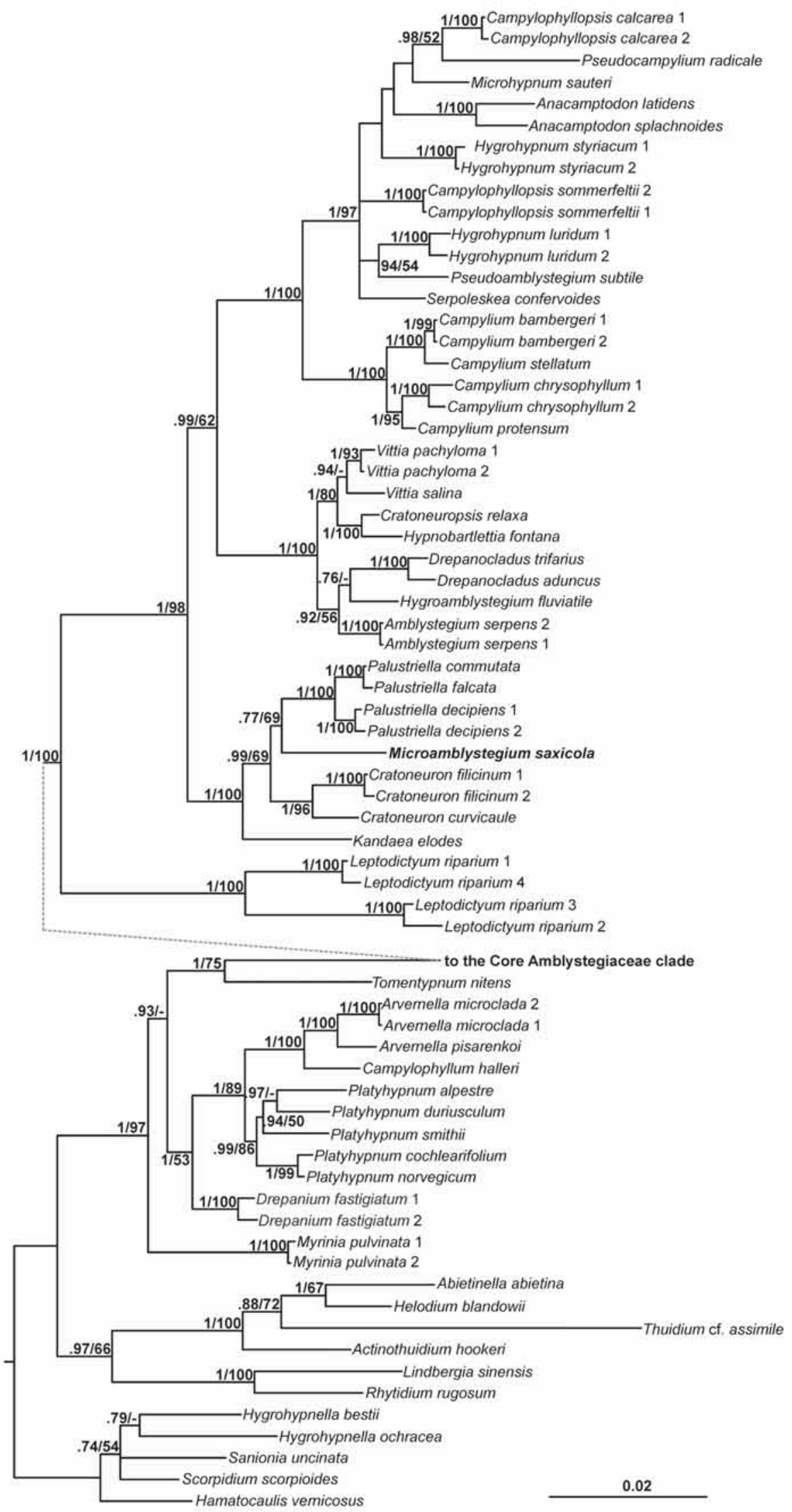

Fig. 1. Bayesian tree of Amblystegiaceae inferred from the combined nuclear and plastid data. Bayesian posterior probabilities higher than 0.7 and Bootstrap support values higher than 50 are shown at branches; «-» indicates low support in the ML tree. 
et al. (2021). Our plant from Shikotan appeared in the well-supported C2 clade (referred to as the clade 2 of the core Amblystegiaceae clade in the Results section), where no such minute mosses have previously been known. Our morphological observations provided insufficient information regarding the affinity of the studied plant. With the combination of small size of plants, not differentiated cells in the stem cross section, ovate-lanceolate, acute to acuminate leaves, weak to moderately developed single costa, short, smooth leaf cells and not or weakly differentiated alar regions, this plant does not exactly match the circumscription of any amblystegiaceous genus. In particular, it differs rather significantly from other species of the C2 clade except for sharing short leaf cells with species of the genus Cratoneuron, where both $C$. filicinum (Hedw.) Spruce and C. curvicaule (Jur.) G. Roth can also form relatively small plants. Other species of the C2 clade are medium-sized to large plants with a well-differentiated stem central strand and sclerodermis, strong costae usually reaching leaf tips, and typically markedly differentiated alar cells in large groups (except for Kandaea). Most species also possess paraphyllia, except Cratoneuron curvicaule and Kandaea (Ignatov \& Ignatova, 2004; Lüth, 2019). Although our plant lacks sporophytes, they usually are not very informative in terms of phylogenetically important traits within the Amblystegiaceae except for several specialized epiphytic lineages.

In its lack of central strand, the plant from Shikotan fits the circumscription of Platydictya sensu Kanda (1976), who considered this genus within the Amblystegiaceae. While it is obvious from recent phylogenies that the type of Platydictya, P. jungermannioides (Brid.) H.A. Crum, together with $P$. acuminata (Lindb. \& Arnell) Ignatov, is a member of the Plagiotheciaceae (Hedenäs \& Pedersen, 2002; Ignatov \& Kuznetsova 2011; Huttunen et al., 2013), the affinities of several insufficiently known Japanese species referred to this genus are unknown. However, none of the species presented by Kanda (1976) and Noguchi (1991) matches satisfactorily our plants (see the Taxonomy section).

Several morphological trends, such as reduction of stem layers, costa and alar cells seem result from parallel evolution associated with miniaturization. Miniaturization is a common adaptive trend in many groups of organisms, which enables them to occupy previously inaccessible niches. In bryophytes, it most prominently occurs in epiphyllous liverworts but there are examples of saxicolous lineages with reduced morphology, particularly among sciotolerant mosses occupying sheltered niches beneath rock overhangs. Examples of such specialized groups include the genera Tetrodontium Schwägr. (reduced central strand and costa), Seligeria Bruch \& Schimp. (reduced central strand), Platydictya (reduced central strand and costa), Heterocladium (in case of $H$. flaccidum (Schimp.) A.J.E. Sm. also with undifferentiated stem cells and costa, in others at least reduced costa), Ignatovia U.B. Deshmukh (reduced central strand),
Serpoleskea (reduced central strand, reduced costa), and Arvernella (reduced central strand and costa). No representative of these reduced saxicolous lineages has welldeveloped and differentiated alar cells, and this appears particularly prominent among other taxa of the $\mathrm{C} 2$ clade of the Amblystegiaceae, which otherwise have the alar cells well-differentiated, together with the strong costa. As a result of such parallelisms extremely similar morphotypes originated in unrelated lineages of mosses, representing unusual instances of cryptic diversity when molecular data reveal new genera or possibly even higher level taxa instead of cryptic species.

Recently, phylogenetic studies have shown that lineages of specialized tiny saxicolous mosses are remarkably phylogenetically isolated, necessitating the erection of new genera based mostly on molecular arguments (Vanderpoorten \& Hedenäs 2009, Ignatov et al., 2019, Ignatov et al., 2021). At the same time, the diversity within such groups of miniaturized saxicolous mosses can be overlooked, as shown in the example of the saxicolous moss genus Heterocladium where most of the described taxa were synonymized with the type species, $H$. heteropterum, in the past, but the molecular diversification accompanied by slight morphological differences could be demonstrated in a recent morpho-molecular study by Hugonnot et al. (2020). It is thus arguable whether the miniaturization in saxicolous bryophytes can be considered as a kind of a dead end of evolution, since all revealed lineages remain monotypic and often thought to be rare or extremely rare, or rather is just the consequence of inadequate exploration of some regions and habitats in combination with the insufficient molecular sampling of seemingly morphologically little variable tiny saxicolous plants. The latter might be more probable, as the relatively recently discovered Arvernella microclada Hugonnot \& Hedenäs (Hugonnot \& Hedenäs, 2015) was described from a bryologically relatively well-known and often visited region and subsequent discovery of this species in likewise well-explored Vosges mountains (Tinguy et al., 2019) seems to confirm this view. Russian Far East and Japan is the area where the diversity of such minute mosses seems to be underexplored, as witnessed by the recent discoveries of Ignatovia microphylla (Ignatov \& Ignatova) U.B. Deshmukh (Ignatov et al., 2019), Arvernella pisarenkoi (Ignatov et al., 2021), and the present find. The status of the earlier described stenotopic temperate East Asian taxa Amblystegium fauriei Broth. \& Paris, Platydictya hattorii Kanda, P. shiroumensis Kanda (cf. Kanda, 1976) and other ones should be revisited in this context and bryologists should be aware of the importance of such unapparent plants which might be genetically isolated and possibly relict, as are the remarkable mosses Takakia S. Hatt. \& Inoue and Oedipodium Schwägr., which also share the habitat of sheltered rock niches with stable humidity and low competition.

Among the advantages of molecular phylogenetic approaches is that they allow an estimation of the phylo- 


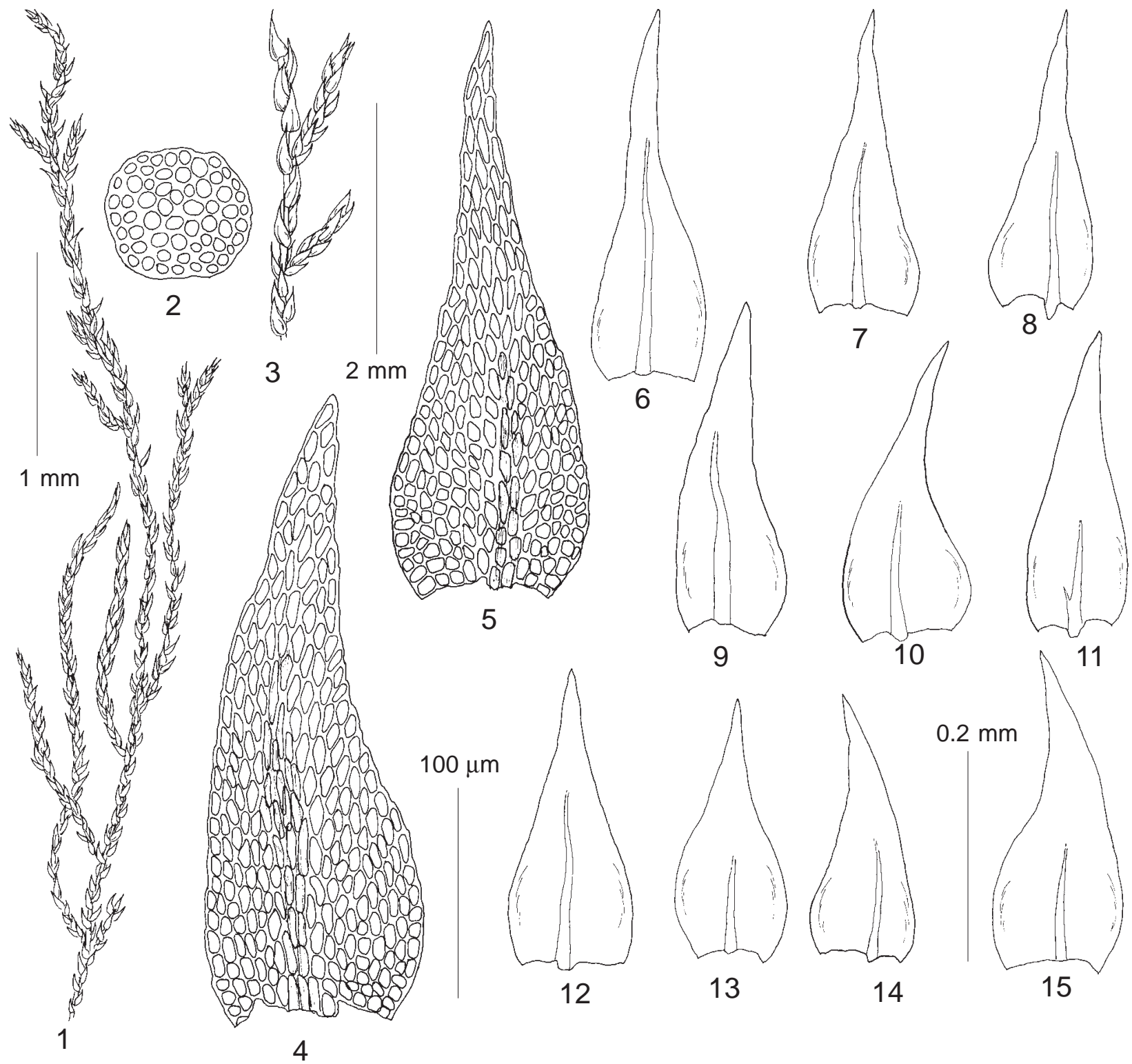

Fig. 2. Microamblystegium saxicola (from holotype). 1, 3: habit, dry; 2: stem transverse section; 4-5: leaf cells; 6-15: stem leaves. Scale bars: $2 \mathrm{~mm}$ for $3 ; 1 \mathrm{~mm}$ for $1 ; 0.2 \mathrm{~mm}$ for $6-15 ; 100 \mu \mathrm{m}$ for $3-5$.

genetic position of a single specimen and therefore, in well sampled groups, enable the description of new taxa based on a single specimen. Earlier this was considered as a rather inappropriate practice since aberrant morphotypes of already known species might be erroneously described as something new, but after the wide introduction of molecular phylogenetic methods several groups were described in such a way (Ignatov et al., 2019; 2021; Bakalin et al., 2021a,b, etc.). Moreover, molecular data provide an essential view of a specimen's affinity in case morphology is incompletely known or uninformative and the identification and description based on traditionally used morphology is thus unreliable. In such a case, sequences obtained from the type specimens become an essential reference, reflecting the identity of the newly described taxa, and should thus be included in the protologue.

\section{TAXONOMY}

Microamblystegium saxicola Fedosov, Ignatova \& Jan Kučera gen. et spec. nov.

Type: Russia, Shikotan Island, Tymovo Distr., vicinity of Malokurilskoe Village, $43.88292^{\circ} \mathrm{N}, 146.83257^{\circ} \mathrm{E}$, $230 \mathrm{~m}$ alt. In shaded niche of rock outcrops. 7 August 2021, coll. Fedosov V.E. \& Shkurko A.V. (holotype MW).

Etymology: The generic name originates from $\mathrm{Am}$ blystegium (a genus of mosses) and refers to its small size. The specific epithet refers to the habitat where it was discovered.

Diagnosis: Microamblystegium differs from most other genera of pleurocarpous mosses in combination of minute size of plants; stem not differentiated internally, composed of thin-walled cells; a weak single costa reaching above mid-leaf at least in several leaves; short and 
wide rhomboidal, smooth laminal cells and scarcely differentiated alar cells. It differs from the similar Arvernella pisarenkoi, Amblystegium fauriei and Platydictya hattorii in a longer single vs. forked costa, somewhat shorter leaf cells and scarcely developed groups of quadrate cells in leaf angles.

Sequences: Plastid, trnS-trnF OL689422; atpB-rbcL OL689420; nr ITS OL689127.

Description. Plants small, in moderately dense, delicate mats, green, yellowish or olivaceous green. Shoots creeping, to $10 \mathrm{~mm}$ long, with terete foliation, loosely irregularly branched, stem in transverse section composed of homogeneous thin-walled cells, without central strand and sclerodermis, outermost cells somewhat smaller, with slightly thicker outer walls than cells inwards; paraphyllia absent. Axillary hairs few, pellucid, 3-4-celled, 30×6 $\mu \mathrm{m}$, apical cell $10 \mu \mathrm{m}$ long; proximal branch leaves of branch primordia variable in size, lanceolate or triangular. Leaves appressed when dry, spreading when moist, $(0.22-) 0.27-0.35(-0.40) \times 0.10-0.13(-0.16) \mathrm{mm}$, from ovate base gradually narrowed into lanceolate or narrowly triangular acumen, apex acute to subobtuse, some leaves with weak shoulders, slightly narrowed to base, not or shortly decurrent, concave; costa single, to $0.3-0.7$ of leaf length, occasionally geniculate, gradually disappearing distally; margins plane, uneven to obtusely serrulate at shoulders; laminal cells rhomboidal or elongate-rhomboidal, (9-)15-17(-25)×5-6(-7) $\mu \mathrm{m}$, with length to width ratio $1.5-2.5(-3): 1$, moderately thick-walled, smooth; cells along margin in 1-2 rows subquadrate to short-rectangular, 9-18×4-6 $\mu \mathrm{m}$, alar cells not or weakly differentiated, subquadrate, transition to adjacent laminal cells gradual. Branch leaves somewhat smaller and narrower than stem leaves. Sexual condition, reproductive structures, and sporophytes unknown.

Differentiation. Microamblystegium saxicola resembles Arvernella pisarenkoi in its combination of small size, sparse branching, not differentiated stem cells in transverse section, rather weak costae, short leaf cells, and saxicolous habitat. It differs from it in single, somewhat longer costae, which typically reach mid-leaf or higher vs. usually forked costae extending to $0.2-0.4$ the leaf length; leaves often with shoulders and narrower acumina vs. gradually tapered into wider acumina, and shorter cells with length/width ratio up to $2.5(-3)$ : 1 vs. usually 3-4:1 in A. pisarenkoi. Microamblystegium saxicola also resembles the insufficiently known Japanese species Amblystegium fauriei, as illustrated by Kanda (1976) from type material, in its stem not differentiated in transverse section, but that species differs in having elongate, thick-walled, prorate laminal cells and subquadrate cells along basal leaf margin in 2-3 rows (in 1 row in Microamblystegium saxicola). The likewise saxicolous Serpoleskea confervoides also lacks a central strand, but has a well-developed sclerodermis. Another minute saxicolous Far Eastern pleurocarpous species, Ignatovia microphylla, differs from Microamblystegium saxicola in having a strong costa nearly reaching the leaf apex, and smaller, rounded, thick-walled laminal cells. The insufficiently known Japanese species Hygroamblystegium calcareum Kanda resembles Microamblystegium saxicola in having a small size, a rather long single costa and weakly differentiated alar cells. However, H. calcareum has a stem with a differentiated sclerodermis and a central strand that differentiate it from M. saxicola. Another small and poorly known amblystegiaceous moss, which likely represents the C2 Amblystegiaceae clade (cf. Kučera \& Hedenäs, 2020), Cratoneuron tenerrimum Kanda, according to illustration in Kanda (1976), also has a well differentiated sclerodermis and central strand in the stem, and its alar group is remarkably differentiated, composed of strongly inflated cells.

Ecology and distribution. The new species is at the moment known from a single locality in the northern part of Shikotan Island. Shikotan differs from all other areas of Russia in a very mild and humid climate. The specimen was collected from shaded humid niche of an acidic rock, where it formed a pure mat. Among other epilithic species growing there, Bryoxiphium japonicum (Berggr.) E. Britton, Calohypnum plumiforme (Wilson) Jan Kučera \& Ignatov, Dozya japonica Sande Lac., and Forsstroemia yezoana (Besch.) S. Olsson, Enroth \& D. Quandt are the most common ones.

\section{ACKNOWLEDGEMENTS}

The work was supported by RSF project 18-14-00121. The work of VF was also supported by contract AAAAA20-120031990012-4 of the Botanical Garden-Institute FEB RAS. The work of AF was also supported by Tsitsin Main Botanical Garden state assignment no. 19119012390082-6 and of EI by Lomonosov Moscow State University state assignment no. 121032500090-7. We also thank the Ministry of Higher Education and Science of the Russian Federation for support and the Center of Collective Use "Herbarium MBG RAS", grant 075-152021-678. Computational resources ('Metacentrum VO') were supplied by the Ministry of Education, Youth and Sports of the Czech Republic under the Projects CESNET (Project No. LM2015042) and CERIT-Scientific Cloud (Project No. LM2015085) provided within the program Projects of Large Research, Development and Innovations Infrastructures.

\section{LITERATURE CITED}

BAKALIN V.A., V.E. FEDOSOV, A.V. FEDOROVA \& W.Z. MA. 2021a. Obtusifoliaceae, a new family of leafy liverworts to accommodate Konstantinovia, newly described from the Hengduan Mts. (South China) and Obtusifolium (Cephaloziineae, Marchantiophyta). - Plant Systematics and Evolution 307: 62 [1-16]. https://doi.org/10.1007/s00606021-01779-8

BAKALIN, V.A., V.E. FEDOSOV, D.G. LONG, A.V. FEDOROVA \& YU. MALTSEVA. 2021b. Protoharpanthus gen. nov. (Harpanthaceae) - a relict relative of Harpanthus from the Sino-Himalaya. - The Bryologist 124(2): 218-229. https://doi.org/10.1639/0007-2745-124.2.218

GARDINER, A., M. IGNATOV, S. HUTTUNEN \& A. TROITSKY. 2005. On resurrection of the families Pseudoleskeaceae Schimp. and Pylaisiaceae Schimp. (Musci, Hypnales). - Taxon 54: 651-663. 
HEDENÄS, L. \& N. PEDERSEN. 2002. Nomenclatural consequences of a phylogenetic study of the Plagiotheciaceae. - Bryologist 105: 325-326.

HUGONNOT, V. \& L. HEDENÄS. 2015. Arvernella microclada Hugonnot \& Hedenäs (Amblystegiaceae), a new minute species from France, requiring a separate genus. - Journal of Bryology 37(3): 184-191.

HUGONNOT, V., I.B. OSMAN, A. DAOUD-BOUATTOUR, S.D. MULLER, A.V. FEDOROVA, E.A. IGNATOVA \& M.S. IGNATOV. 2020. A Range Extension of Heterocladium flaccidum (Schimp.) A.J.E.Sm. to Africa and Asia and Confirmation of Its Specific Status. Cryptogamie Bryologie. 41(21):265-272. https://doi.org/10.5252/cryptogamie-bryologie2020v41a21

HUTTUNEN, S., M.S. IGNATOV, D. QUANDT \& L. HEDENÄS. 2013. Phylogenetic position and delimitation of the moss family Plagiotheciaceae in the order Hypnales. - Botanical Journal of the Linnean Society 171(2): 330-353. https://doi.org/10.1111/j.10958339.2012.01322.x

IGNATOV, M.S., O.D. DUGAROVA, A.V. FEDOROVA \& E.A. IGNATOVA. 2019. Lazarenkoa, a new moss genus from the Russian Far East. - Arctoa 28: 226-230.

[IGNATOV, M.S. \& E.A. IGNATOVA] ИГНАТOB M.C., Е.A. ИГНАТОВА. 2004. Флора мхов средней части европейской России. T. 2. - [Moss flora of the Middle European Russia. Vol. 2] M., KMK [Moscow, KMK]: 609-960.

IGNATOV, M.S., E.A. IGNATOVA \& O.I. KUZNETSOVA. 2021. A rare European endemic moss genus Arvernella is discovered in Sakhalin, Russian Far East, where it is also rare. - Arctoa 30: 1-7. doi: 10.15298/ arctoa.30.01

IGNATOV, M.S. \& O.I. KUZNETSOVA. 2011. On the taxonomy of Myurella-Platydictya complex (Plagiotheciaceae, Bryophyta). - Arctoa 20: 239-246.

KANDA, H. 1975[1976]. A revision of the family Amblystegiaceae of Japan I. - Journal of Science of the Hiroshima University, Series B, Division 2 (Botany) 15: 201-276.

KATOH, K. \& D.N. STANDLEY. 2013. MAFFT Multiple sequence alignment software version 7: improvements in performance and usability. Molecular Biology and Evolution 30(4): 772-780.

KUČERA, J., O.I. KUZNETSOVA, A. MANUKJANOVÁ \& M.S. IGNATOV. 2019. A phylogenetic revision of the genus Hypnum: towards completion. - Taxon 68(4): 628-660.

KUČERA J. \& L. HEDENÄS. 2020. Revisiting the genus Campyliadelphus (Amblystegiaceae, Bryophyta). - Nova Hedwigia Beiheft 150: 165-178. doi: $10.1127 /$ nova-suppl/2020/165
LÜTH, M. 2019. Mosses of Europe - a photographic flora. - Freiburg, $M$. Lüth, 1: 1-328, 2: 329-840, 3: 841-1360..

MILLER, M.A., W. PFEIFFER \& T. SCHWARTZ. 2010. Creating the CIPRES Science Gateway for inference of large phylogenetic trees. In: Proceedings of the Gateway Computing Environments Workshop (GCE), 14 Nov. 2010, New Orleans, LA: 1-8.

MÜLLER, K. 2005. SeqState. - Applied Bioinformatics 4 (1): 65-69.

NOGUCHI, A. 1991. Illustrated Moss Flora of Japan. Vol. 4. - Nichinan, Hattori Botanical Laboratory: pp. 743-1012.

RAMBAUT, A., A.J. DRUMMOND, D. XIE, G. BAELE \& M.A. SUCHARD. 2018. Posterior Summarization in Bayesian Phylogenetics Using Tracer 1.7. - Systematic Biology 67: 901-904. https://doi.org/ 10.1093/sysbio/syy032

RONQUIST, F., M. TESLENKO, P. VAN DER MARK, D.L. AYRES, A. DARLING, S. HÖHNA, B. LARGET, L. LIU, M.A. SUCHARD \& J.P. HUELSENBECK. 2012. MrBayes 3.2: Efficient Bayesian Phylogenetic Inference and Model Choice Across a Large Model Space. Systematic Biology 61: 539-542. https://doi.org/10.1093/sysbio/ sys029

SIMMONS, M.P. \& H. OCHOTERENA. 2000. Gaps as Characters in Sequence-Based Phylogenetic Analyses. - Systematic Biology 49: 369 381. https://doi.org/10.1093/sysbio/49.2.369

STAMATAKIS, A. 2014. RAxML version 8: a tool for phylogenetic analysis and post-analysis of large phylogenies. - Bioinformatics 30: 1312 1313. https://doi.org/10.1093/bioinformatics/btu033

TINGUY, H., V. HUGONNOT, B. STOEHR \& F. BICK. 2019. Arvernella microclada (Amblystegiaceae) newly reported in Vosges (Alsace, France). - Herzogia 32: 200-208. https://doi.org/10.13158/ heia.32.1.2019.200

VANDERPOORTEN, A. \& L. HEDENÄS. 2009. New combinations in the Amblystegiaceae. - Journal of Bryology 31: 129-132.

VANDERPOORTEN, A., L. HEDENÄS, C.J. COX \& A.J. SHAW. 2002. Circumscription, classification, and taxonomy of Amblystegiaceae (Bryopsida) inferred from nuclear and chloroplast DNA sequence data and morphology. - Taxon 51: 115-122.

VANDERPOORTEN, A., A. SHAW \& B. GOFFINET. 2001. Testing controversial alignments in Amblystegium and related genera (Amblystegiaceae: Bryopsida). Evidence from rDNA ITS sequences. - Systematic Botany 26: 470-479.

Appendix 1. Sequences used for molecular phylogenetic study. Specimens originally studied in course of the present study in newly obtained sequences are shown in bold.

\begin{tabular}{|c|c|c|c|c|}
\hline species & voucher/isolate & ITS & $\operatorname{trnL}-\operatorname{trnF}$ & AtpB-rbcL \\
\hline Abietinella abietina & Allen 19816 & AY009802 & AY009850 & AF322308 \\
\hline Actinothuidium hookeri & Yunan & KF770664 & KF770502 & KF770610 \\
\hline Amblystegium serpens 1 & Czechia, Osule, Kučera 20081CBFS & MK327283 & MK313964 & MK313876 \\
\hline Amblystegium serpens 2 & S B55399 Vanderpoorten 4158 & FJ535778 & FJ535739 & FJ535758 \\
\hline Anacamptodon latidens & Kučera 18134 & MK327284 & MK313965 & MK313877 \\
\hline Anacamptodon splachnoides & Schofield et al. 96529 & AY009810 & AY009816 & AF322336 \\
\hline Arvernella microclada 1 & Hugonnot CBNMC 5186 & KC914873 & KC914874 & KC914875 \\
\hline Arvernella microclada 2 & Kučera 18824 CBFS & MH613350 & MH613576 & MH613491 \\
\hline Arvernella pisarenkoi & $\begin{array}{l}\text { OK106, Sakhalin Province, Sakhalin Island, } \\
\text { Pisarenko op03738 MHA }\end{array}$ & MZ417374 & OL689423 & MZ447838 \\
\hline Microamblystegium saxicola & $\begin{array}{l}\text { BF44, Russia, Sakhalin Province, Shikotan Island, } \\
\text { 7.VIII.2021 Fedosov s.n., MW }\end{array}$ & OL689127 & OL689422 & OL689420 \\
\hline Campylium bambergeri 1 & Kučera 15845 CBFS & MK327315 & MK313997 & MK313909 \\
\hline Campylium bambergeri 2 & Scharnock 9204 & MH613390 & MH613616 & MH613516 \\
\hline Campylium chrysophyllum 1 & Anderson 26799 & AF168150 & AF161141 & AF322355 \\
\hline Campylium chrysophyllum 2 & Kučera 15609 & MH613361 & MH613587 & MH613496 \\
\hline Campylium protensum & Kučera 13219 CBFS & MH613364 & MH613590 & MH613499 \\
\hline Campylium stellatum & Kučera 15972 CBFS & MK327292 & MK313974 & MK313886 \\
\hline
\end{tabular}


Campylophyllopsis calcarea 1 Ca2022, Czechia, Horni Alberice, Kučera 22342 CBFS

Campylophyllopsis calcarea 2 Navarov 14800

Campylophyllopsis sommerfeltii 1 Hedenäs, S B175748

Campylophyllopsis sommerfeltii 2 Ca2020, Czechia, Salajka,

Campylophyllum halleri Cratoneuron curvicaule Cratoneuron filicinum 1 Cratoneuron filicinum 2 Cratoneuropsis relaxa

Drepanium fastigiatum 1 Drepanium fastigiatum 2 Drepanocladus aduncus Drepanocladus trifarius Hamatocaulis vernicosus Helodium blandowii Hygroamblystegium fluviatile Hygrohypnella bestii species

Hygrohypnella ochracea Hygrohypnum luridum 1 Hygrohypnum luridum 2 Hygrohypnum styriacum 1 Hygrohypnum styriacum 2 Hypnobartlettia fontana Kandaea elodes Leptodictyum riparium 1 Leptodictyum riparium 2 Leptodictyum riparium 3 Leptodictyum riparium 4 Lindbergia sinensis Microhypnum sauteri Myrinia pulvinata 1 Myrinia pulvinata 2

Palustriella commutata Palustriella decipiens 1 Palustriella decipiens 2 Palustriella falcata Platyhypnum alpestre Platyhypnum cochlearifolium Platyhypnum duriusculum Platyhypnum norvegicum Platyhypnum smithii Pseudoamblystegium subtile Pseudocampylium radicale Rhytidium rugosum Sanionia uncinata Scorpidium scorpioides Serpoleskea confervoides Thuidium cf. assimile Tomentypnum nitens Vittia pachyloma 1 Vittia pachyloma 2 Vittia salina

Lewis 87262
25.IX.2019 Mikulaskova, CBFS22454

Kučera 18388

Kučera 15725, CBFS

Kučera 18759, CBFS

Streimann 49394

Kučera 12468

Kučera 18282

S B1047

S B73402

S B1068

Schofield 108637

Vanderpoorten 3739

Schofield S B81888

voucher/isolate

S B818976

Kučera 18482 CBFS

S B81975

CBFS18850

S B81902

isolate Hypno.1477

Kučera 20960 CBFS

Kučera 17055

LF1, Russia, Vladimir Province, MW6046724

LF5, Russia, Tatarstan Republic, MW9046928

LF8, Russia, Volgograd Province, MW9046941

Jiangsu

Kučera 16814

Chernyadyeva 3.VII.2015

ThF11, Russia, Nenets autonomous Distr., MHA9024223

Kučera 20946 CBFS

Kučera 20956 CBFS

MACB 90037

S B 61810

S B81980

S B81890

Kučera 10940

S B81898

Schofield 104556

Kučera 16368

Kučera 18708

Kučera 12871

S B96458

S B61836

Kučera 14744

Yunnan

Schofield 103470

Goffinet 5605

isolate Vittia1303

isolate Vittia1466
OL740037

OL792053

OL792051

MH613366

MH613368

OL740036

MH613592

MH613501

MH613594

MH613502

MK327293

MN646798

MN646797

AF168155

FJ535787

MH613449

MK327338

EU216317

KC601928

AY625994

AY009803

AF464979

AY857598

ITS

AY857605

MH613385

AY857601

MH613386

AY 857608

AY242368

MN646796

MH613473

OL6891231

OL6891230

OL689129

KF770668

MH613460

MK327351

OL689128

MN646799

MN646800

AY857615

GU237137

AY857596

AY857599

MH613476

AY857604

AY857607

MH613478

MH613480

MK327361

GQ849964

AY625995

MH613488

KF770638

AF168161

AY062886

AY242367

AY242370
OL792052

OL792050

MK313975

MN635410

MN635411

AY009817

FJ535748

MH613674

MK314022

EU216109

FJ535737

AY626012

AY009852

AF465000

AY857555

trnL-trnF

AY 857563

MH613611

AY857559

MH613612

AY857566

AY242376

MN635412

MH613698

OL689427

OL689426

OL689425

KF770506

MH613684

MK314034

OL689424

MK313887

MN635403

MN635404

AF322332

FJ535768

MH613552

MK313936

FJ535761

FJ535756

AY625976

AF322313

AF464956

AY857576

AtpB-rbcL

AY857584

MH613512

AY857580

MH613513

AY857587

HQ268437

MN635405

MH613564 -

KF770614

MH613558

MK313949

OL689421

MN635409

MN635402

MN635408 MN635401 AY857572

AY 626006

AY857553

AY857556

MH613701

AY857562

AY857565

MH613703

MH613705

MK314044

GQ849841

AY626014

MH613713

KF770476

AY009854

AY062889

AY242375

AY242378

AY857594

AY625966

AY857574

AY857577

AY 857583

AY857586

MH613566

MH613568

MK313960

AF322321

AY 625977

MH613573

KF770584

AF322352

AY062883

AY24236
AY242358 